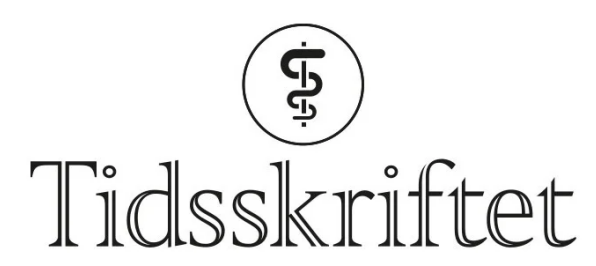

DEN NORSKE LEGEFORENING

\title{
Covid-19 hos pasienter med kronisk inflammatorisk leddsykdom
}

ORIGINALARTIKKEL

\section{TONE WIKENE NYSTAD}

tone.wikene.nystad@helse-bergen.no Norsk kvalitetsregister for artrittsykdommer Haukeland universitetssjukehus og Revmatologisk avdeling Haukeland universitetssjukehus Hun har bidratt med planlegging, tolkning av statistiske analyser og skriving av manuskriptet. Tone Wikene Nystad er ph.d., spesialist i revmatologi, overlege og nestleder av Norsk kvalitetsregister for artrittsykdommer.

Forfatteren har fylt ut ICMJE-skjemaet og oppgir ingen interessekonflikter.

\section{KARL OVE HUFTHAMMER}

Kompetansesenter for klinisk forsking

Forskings- og utviklingsavdelinga

Haukeland universitetssjukehus

Han har bidratt med planlegging, bearbeiding av data, statistisk analyse, utforming av figurer og revidering av manuskriptet.

Karl Ove Hufthammer er ph.d. og jobber som biostatistiker.

Forfatteren har fylt ut ICMJE-skjemaet og oppgir ingen interessekonflikter.

\section{EIRIK ALNES BUANES}

Norwegian Intensive Care and Pandemic Registry (NIPaR)

Bergen Health Trust

and

Department of Anaesthesiology and Intensive Care

Haukeland University Hospital

He has contributed to the design of the project, collection and interpretation of data, and drafting and revision of the submitted manuscript version.

Eirik Alnes Buanes, head of the Norwegian Intensive Care and Pandemic Registry and senior consultant.

The author has completed the ICMJE form and declares no conflicts of interest.

\section{KJARTAN BRYNE}

\section{Revmatologisk avdeling}

Haukeland universitetssjukehus

Han har bidratt med planlegging og skriving av manuskriptet.

Kjartan Bryne er lege i spesialisering i revmatologi og overlege.

Forfatteren har fylt ut ICMJE-skjemaet og oppgir ingen interessekonflikter. 
Norsk kvalitetsregister for artrittsykdommer Haukeland universitetssjukehus

og

Revmatologisk avdeling

Haukeland universitetssjukehus

og

Klinisk institutt 2

Universitetet i Bergen

Hun har bidratt med planlegging, tolkning av statistiske analyser og skriving av manuskriptet.

Bjørg-Tilde Svanes Fevang er professor og spesialist i revmatologi, overlege og leder av Norsk kvalitetsregister for artrittsykdommer.

Forfatteren har fylt ut ICMJE-skjemaet og oppgir ingen interessekonflikter.

\section{BAKGRUNN}

Siden pasienter med kronisk inflammatorisk leddsykdom kan være mer utsatt for infeksjoner, ønsket vi å undersøke forekomsten av covid-19 i denne gruppen og se om forhold ved den revmatiske sykdommen, pasienten eller behandlingen hadde betydning.

\section{MATERIALE OG METODE}

27907 pasienter registrert i Norsk kvalitetsregister for artrittsykdommer (NorArtritt) ble koblet til Meldingssystem for smittsomme sykdommer og Norsk intensiv- og pandemiregister for å finne forekomsten av covid-19 i 2020 og andel innlagt i sykehus. Standardisert insidensforhold (SIR) ble beregnet ved sammenligning med kjønns- og aldersspesifikk forekomst i den generelle befolkningen. Ved logistisk regresjonsanalyse ble det undersøkt om diagnose, alder, kjønn, sykdomsaktivitet, komorbiditet eller medikamentell behandling hadde betydning for forekomsten.

\section{RESULTATER}

185 av pasientene i NorArtritt fikk påvist covid-19, hvorav 10 \% ble innlagt på sykehus. Forekomsten var lavere enn i den generelle befolkningen (SIR o,84; 95 \%-konfidensintervall (KI): 0,72 til o,97, P = 0,02). Ung alder og lav sykdomsaktivitet var knyttet til høyere smitteforekomst. De andre faktorene hadde ingen signifikant betydning.

\section{FORTOLKNING}

At forekomsten av covid-19 var lavere enn i normalbefolkningen og innad i gruppen lavere hos dem med moderat/høy sykdomsaktivitet og høyere alder, skyldes trolig at pasienter med kronisk aktiv sykdom og høy alder i større grad har beskyttet seg mot smitte.

\section{HOVEDFUNN}

Pasienter med kronisk inflammatorisk leddsykdom hadde lavere forekomst av covid-19 enn befolkningen generelt.

Innad i gruppen hadde yngre pasienter og pasienter med lav sykdomsaktivitet høyere forekomst av smitte.

Kroniske inflammatoriske leddsykdommer er en samlebetegnelse på tilstander karakterisert ved ikke-infeksiøs betennelse i ledd og/eller ryggsøyle. Sykdommene som inkluderes, er blant annet revmatoid artritt, psoriasisartritt og spondyloartritter. Både sykdommene i seg selv og behandlingen, som ofte innebærer immunsuppresjon, kan medføre økt risiko for infeksjoner (1-3). Etter utbruddet av covid-19 har vi ved revmatologiske avdelinger opplevd stor pågang både fra pasienter og helsepersonell med spørsmål om eventuell risiko forbundet med bruk av immunsupprimerende 
medikamenter og om pasientgruppen anses som en risikogruppe. Basert på nasjonale og internasjonale anbefalinger har vårt råd til pasientene vært at de bør fortsette med sine vanlige medisiner så lenge de ikke har symptomer på infeksjon (4),5). Dokumentasjonen for disse anbefalingene har vært begrenset.

I noen studier har man funnet at pasienter med revmatisk sykdom hadde høyere forekomst av covid-19 ( $(\underline{6}, 7$.$) , mens andre ikke har gjort tilsvarende funn, heller ikke om pasienten$ brukte konvensjonelle sykdomsmodifiserende medikamenter (므). I én studie var bruk av biologiske eller målrettede syntetiske sykdomsmodifiserende medikamenter risikofaktor for smitte ( $\underline{8})$, mens to andre studier ikke fant noen slik sammenheng $(9, \underline{10})$.

I flere av studiene er diagnose basert på symptomer og smitteeksponering, uten krav om positiv laboratoriebasert testing. Studiene er små, og selv om antallet publikasjoner er stigende, er det fortsatt uavklart hvorvidt pasienter med kronisk inflammatorisk leddsykdom har $\emptyset \mathrm{kt}$ smitterisiko.

Det er heller ikke klart om disse pasientene får et mer alvorlig forløp ved covid-19. Noen studier har funnet høyere forekomst av intensivopphold (11) og behov for mekanisk ventilasjon $(\underline{11}, \underline{12})$ hos pasienter med revmatisk sykdom. Det er også funnet høyere risiko for innleggelse hos pasienter med revmatisk sykdom som bruker prednisolon i doser $\geq 10 \mathrm{mg}$ daglig (13). Andre studier har ikke funnet mer alvorlige forløp enn hos den generelle befolkningen $(\underline{14}, 15)$.

I en nylig publisert norsk studie ble det ikke funnet $\emptyset \mathrm{kt}$ forekomst av inflammatoriske leddsykdommer blant pasienter positive for SARS-CoV-2 eller pasienter innlagt med covid19 sammenlignet med den generelle befolkningen (16).

Formålet med vår studie var å undersøke forekomsten av covid-19 blant pasienter med kronisk inflammatorisk leddsykdom i Norge sammenliknet med den generelle befolkningen. Vi ønsket også å se om faktorer ved den revmatiske sykdommen, pasienten eller den medikamentelle behandlingen hadde betydning for forekomsten. Videre ville vi undersøke hvor stor andel av de smittede som trengte sykehusinnleggelse og intensivbehandling.

\section{Materiale og metode}

\section{DATAMATERIALE}

Norsk kvalitetsregister for artrittsykdommer (NorArtritt) har data fra ca. 30 ooo pasienter med kronisk inflammatorisk leddsykdom i Norge, og har en dekningsgrad på 6o \% på landsbasis (17.). Det registreres blant annet opplysninger vedrørende sykdommene, komorbiditet, høyde, vekt og medikamentell behandling. Meldingssystem for smittsomme sykdommer (MSIS) bidrar til overvåkning av smittsomme sykdommer i Norge. Tilfeller av covid-19 meldes direkte fra laboratoriet. Norsk intensiv- og pandemiregister inneholder opplysninger om alle pasienter med covid-19 som innlegges i sykehus. Registeret har en dekningsgrad på $99 \%(\underline{18})$.

Vi utførte en registerbasert historisk kohortstudie der forekomst av covid-19 ble unders $ø$ kt for pasienter i NorArtritt. Data ble hentet ut fra NorArtitt 10. september 2020, og alle pasienter som var i live 1. januar 2020, ble inkludert i kohorten. Data fra registeret ble koblet til MSIS for å finne pasienter smittet med SARS-CoV-2 innen 31. desember 2020. Det ble også utført kobling til Norsk intensiv- og pandemiregister for å se på forekomsten av sykehusinnleggelse, intensivopphold og mekanisk ventilasjon.

Vi har i denne studien kategorisert pasientene i fire diagnosegrupper - revmatoid artritt, psoriasisartritt, spondyloartritt og andre perifere artritter - ut ifra nyeste registrerte ICD-10diagnosekoder (International Classification of Diseases, Tenth Revision (19.)).

Sykdomsaktivitet og andre bakgrunnsvariabler ble hentet fra nyeste registrering for pasienter som ikke ble smittet, og fra siste registrering før positiv SARS-CoV-2-PCR for 
pasienter som ble smittet. Sykdomsaktiviteten ved perifere artritter angis ved Disease Activity Score 28 (DAS28-CRP). DAS28-CRP <3,2 regnes som remisjon / lav sykdomsaktivitet og DAS28-CRP $\geq 3,2$ som moderat/høy sykdomsaktivitet (200). Sykdomsaktiviteten ved spondyloartritter angis ved Ankylosing Spondylitis Disease Activity Score (ASDAS-CRP). ASDASCRP <2,1 regnes som remisjon / lav sykdomsaktivitet og ASDAS-CRP $\geq 2,1$ som moderat/høy sykdomsaktivitet (1ㅡ). Vi så også på bruk av prednisolon og sykdomsmodifiserende medikamenter.

For å kunne studere hvorvidt det forelå under- eller overhyppighet av covid-19, ble det innhentet tall fra MSIS for antall smittede i den generelle norske befolkningen oppgitt per kjønn og ettårig aldersgruppe (alder ved 1. januar 2020). Disse ble koblet med

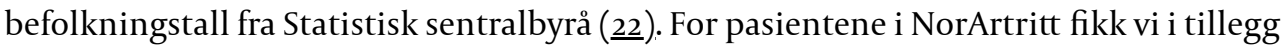
informasjon om smittedato.

Alle inkluderte individer har samtykket til deltakelse i NorArtritt og til kobling av data med andre helseregistre. Studien er godkjent av regional etisk komite (REK vest-139796), og før kobling av data vurderte personvernombudet ved Helse Bergen eventuelle personvernkonsekvenser.

STATISTISKE ANALYSER

Hovedutfallsmål var tilfeller av covid-19 meldt til MSIS. For å undersøke om det forelå overhyppighet, sammenlignet vi antall pasienter med covid-19 i NorArtritt med forventet antall basert på kjønns- og aldersspesifikk forekomst i den generelle norske befolkningen (indirekte standardisering). Vi rapporterer den relative hyppigheten som standardisert insidensforhold (standardised incidence ratio, SIR) med 95\%-konfidensintervall (KI).

For å undersøke hvilke bakgrunnsvariabler som var knyttet til forekomsten av covid-19, brukte vi multippel logistisk regresjon. Forklaringsvariablene var alder, kjønn, diagnosegruppe, remisjonsstatus, C-reaktivt protein (CRP), kroppsmasseindeks (KMI), antall komorbiditeter og medikamentell behandling. Medikamentell behandling ble delt $\mathrm{i}$ tre grupper: kortikosteroider, konvensjonelle syntetiske sykdomsmodifiserende medikamenter og biologiske eller målrettede syntetiske sykdomsmodifiserende medikamenter (se tabell 1 for beskrivelse av medikamentklasser).

\section{Tabell 1}

Grupper av sykdomsmodifiserende medikamenter brukt ved revmatiske sykdommer og noen eksempler på medikamentklasser og medikamenter.

\begin{tabular}{|llll|}
\hline Forkortelse & Beskrivelse & Medikamentklasser & Medikamenter \\
\hline csDMARD & $\begin{array}{l}\text { Conventional synthetic } \\
\text { disease modifying anti- } \\
\text { rheumatic drug }\end{array}$ & $\begin{array}{l}\text { Metotreksat, } \\
\text { sulfasalazin }\end{array}$ & \\
\hline bDMARD & $\begin{array}{l}\text { Biologic disease } \\
\text { modifying anti- } \\
\text { rheumatic drug }\end{array}$ & $\begin{array}{l}\text { Tumornekrosefaktor-alfa } \\
\text { (TNF-alfa)-hemmere, } \\
\text { B-cellehemmere }\end{array}$ & $\begin{array}{l}\text { Infliksimab, etanercept, } \\
\text { rituksimab }\end{array}$ \\
\hline tsDMARD & $\begin{array}{l}\text { Targeted synthetic } \\
\text { disease modifying anti- } \\
\text { rheumatic drug }\end{array}$ & $\begin{array}{l}\text { Janus kinase (JAK)- } \\
\text { hemmere }\end{array}$ & Baricitinib, tofacitinib \\
\hline
\end{tabular}

Vi antok at det kunne være en ikke-lineær sammenheng med alder, så alderseffekten ble modellert som en naturlig spline med knuter ved 10-, 50- og 90-prosentilen. De kontinuerlige variablene CRP, KMI og antall komorbiditeter ble modellert som lineære effekter, men begrenset oppad (winsorisert) til henholdsvis $100 \mathrm{mg} / \mathrm{L}, 50 \mathrm{~kg} / \mathrm{m}^{2} \mathrm{og}_{5}$, både 
for å unngå eventuell urimelig påvirkning av høye/ekstreme verdier og fordi vi antok at effektene ville flate ut for høye verdier. Vi tok sikte på å ha minst ti covid-19-tilfeller per forklaringsvariabel/koeffisient.

Vi beregnet også andelen av de smittede i NorArtritt som ble innlagt i sykehus, og som hadde behov for intensivopphold eller mekanisk ventilasjon. Alle statistiske analyser ble gjort med R versjon 4.0.4 (23). Signifikansnivået ble satt til $5 \%$.

\section{Resultater}

Antall pasienter i hver analyse er presentert i figur 1. Av 27907 pasienter med kronisk inflammatorisk leddsykdom var 185 (o,66\%) registrert smittet med SARS-CoV-2. Forventet antall basert på kjønns- og aldersjustert norsk befolkning var 220, noe som gir et standardisert insidensforhold på o,84 (95\%-KI: o,72 til o,97, P = o,02). Fordelt på kjønn var insidensforholdet 0,93 for kvinner og o,73 for menn (tabell 2), men kjønnsforskjellen var ikke statistisk signifikant $(\mathrm{P}=0,09)$. Andel smittede innen hver alders- og kjønnskategori sammenlignet med den generelle befolkningen er presentert i tabell 2. Figur 2 viser antall smittede per måned.

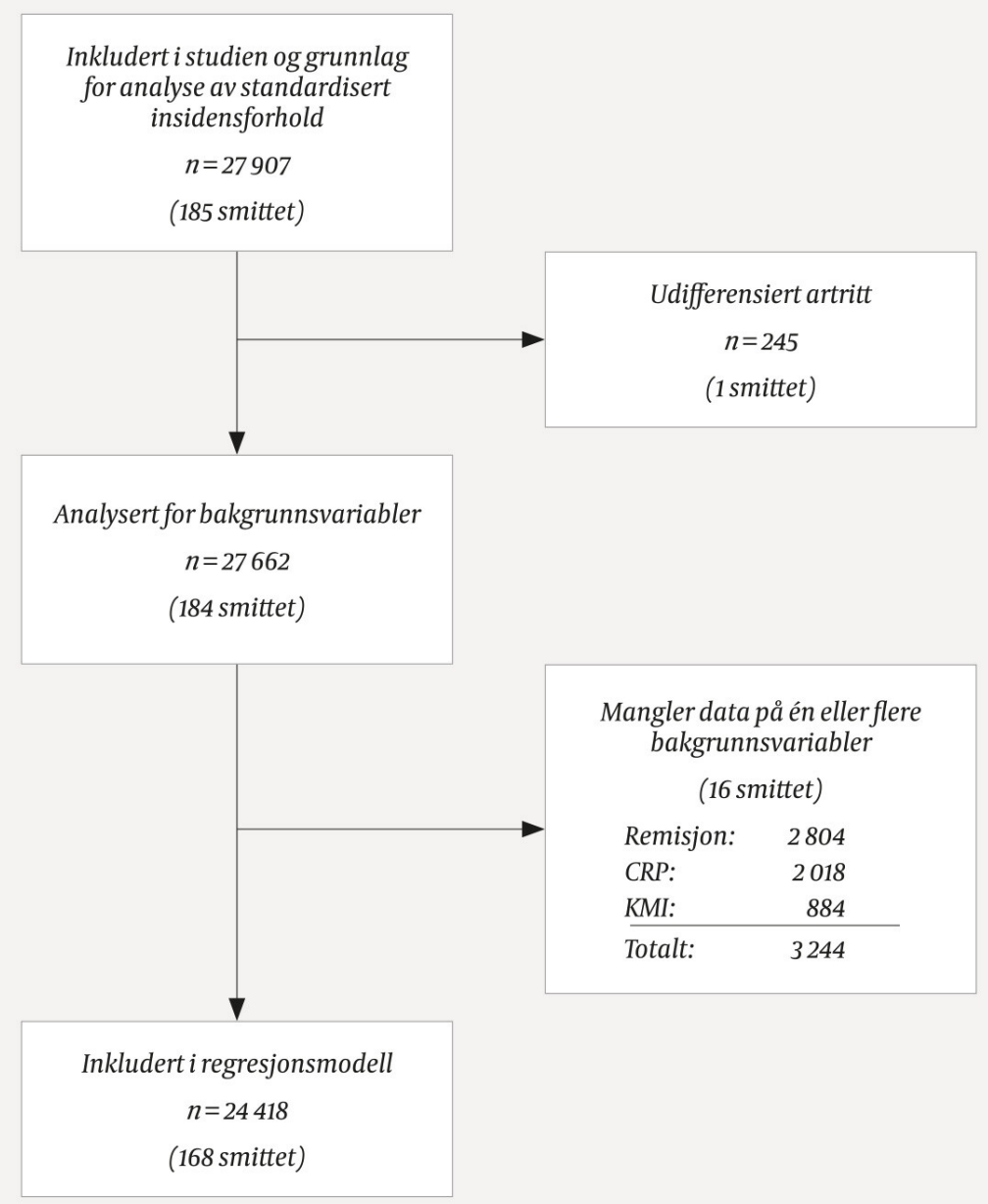

Figur 1 Flytskjema over pasienter inkludert $\mathrm{i}$ hver analyse. $\mathrm{CRP}=\mathrm{C}$-reaktivt protein, $\mathrm{KMI}=$ kroppsmasseindeks.

\section{Tabell 2}


SARS-CoV-2-smitte i 2020 blant NorArtritt-pasienter $(n=27907)$ og generell norsk befolkning stratifisert på kjønn og alder (per 1. januar 2020, data fra MSIS). Det var en generell underhyppighet av smitte blant NorArtritt-pasienter, med et standardisert insidensforhold på o,84 (95\%-KI: o,72 til o,97). Fordelt på kjønn var det 0,93 (95\%-KI: o,77 til 1,11) for kvinner og 0,73 (95\%-KI: 0,57 til o,91) for menn.

\begin{tabular}{|c|c|c|c|c|c|c|c|c|}
\hline \multirow[b]{3}{*}{ Alder } & \multicolumn{4}{|l|}{ Kvinner } & \multicolumn{4}{|l|}{ Menn } \\
\hline & NorArtri & & & Norge & NorArtri & & & Norge \\
\hline & Positive & Totalt & $\begin{array}{l}\text { Andel } \\
\text { (\%) }\end{array}$ & $\begin{array}{l}\text { Andel } \\
(\%)\end{array}$ & Positive & Totalt & $\begin{array}{l}\text { Andel } \\
\text { (\%) }\end{array}$ & $\begin{array}{l}\text { Andel } \\
(\%)\end{array}$ \\
\hline $16-29$ & 8 & 640 & 1,25 & 1,43 & 4 & 457 & 0,88 & 1,44 \\
\hline $30-39$ & 11 & 1425 & 0,77 & 1,06 & 9 & 1121 & 0,80 & 1,29 \\
\hline $40-49$ & 30 & 2495 & 1,20 & 1,04 & 19 & 1919 & 0,99 & 1,14 \\
\hline $50-59$ & 17 & 3699 & 0,46 & 0,88 & 21 & 2832 & 0,74 & 1,00 \\
\hline $60-69$ & 17 & 4194 & 0,41 & 0,52 & 10 & 2762 & 0,36 & 0,64 \\
\hline 70-79 & 21 & 3127 & 0,67 & 0,41 & 9 & 1896 & 0,47 & 0,46 \\
\hline $80+$ & 9 & 922 & 0,98 & 0,57 & 0 & 418 & 0,00 & 0,53 \\
\hline Totalt & 113 & 16502 & 0,68 & 0,94 & 72 & 11405 & 0,63 & 1,05 \\
\hline Forventet $^{1}$ & 121 & 16502 & 0,73 & - & 99 & 11405 & 0,87 & - \\
\hline
\end{tabular}

${ }^{1}$ Forventet antall smittede NorArtritt-pasienter dersom kjønns- og aldersspesifikk forekomst (basert på ettårsaldersgrupper) var som i den generelle norske befolkningen. 


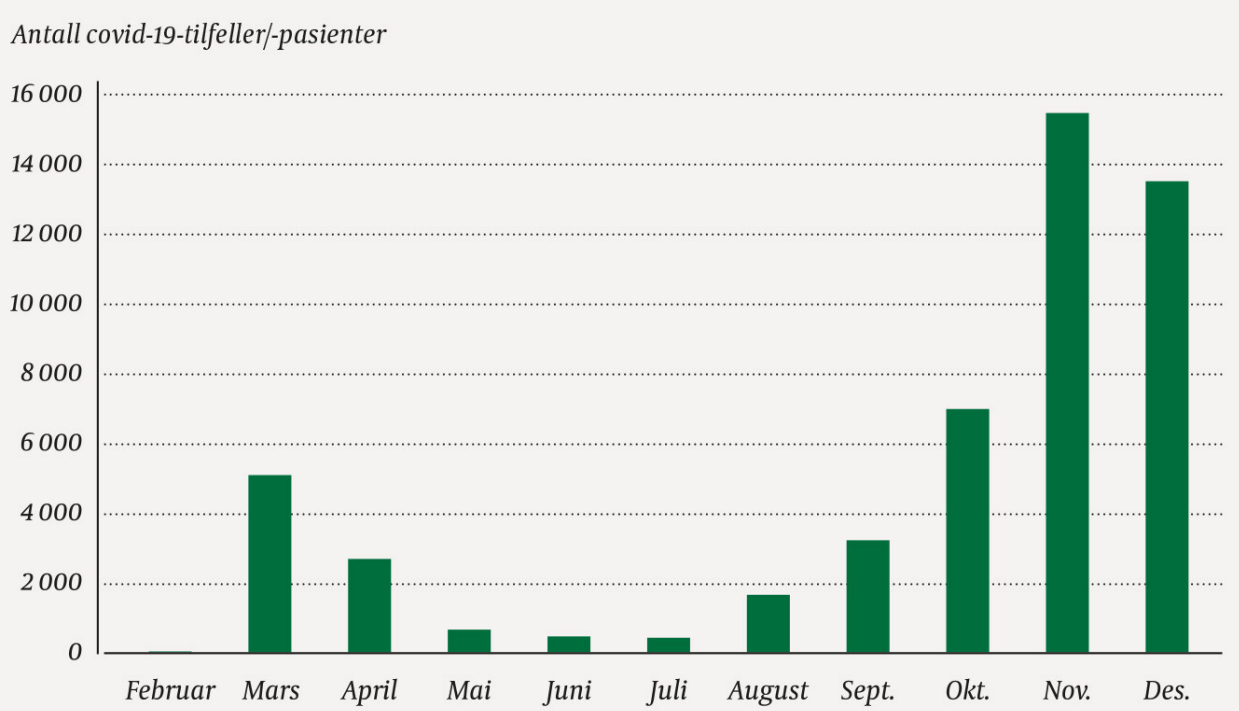

a. Generell norsk befolkning

Antall covid-19-tilfeller-pasienter

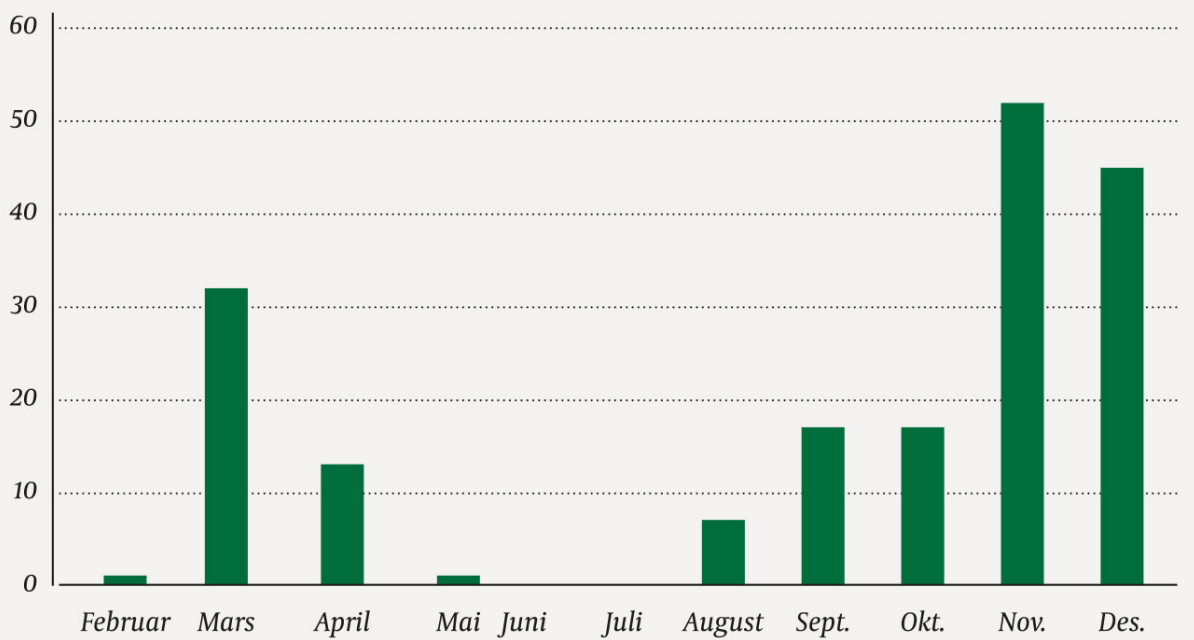

b. Norsk kvalitetsregister for artrittsykdommer

Figur 2 Antall covid-19-tilfeller per måned i 2020 for den generelle norske befolkningen ( $\mathrm{n}=$ $50148)$ og pasienter registrert i Norsk kvalitetsregister for artrittsykdommer $(n=185)$. Kjønns- og alderssammensetningen er ikke identisk i de to populasjonene, men smittemønsteret fremstår likt. Data for smittede i den generelle norske befolkningen er hentet fra Folkehelseinstituttet (29).

Antall smittede i NorArtritt-populasjonen og i hver undergruppe er angitt i tabell 3. Én pasient lot seg ikke klassifisere i de fire diagnosegruppene (udifferensiert artritt) og er ekskludert fra analysen. Resultatene fra regresjonsanalysen er angitt i tabell 4. Lavere alder og at pasienten hadde lav sykdomsaktivitet eller var i remisjon, var knyttet til høyere forekomst av covid-19. Kjønn, diagnose, medikamentell behandling, KMI eller komorbiditet hadde ingen signifikant betydning.

\section{Tabell 3}


Bakgrunnsvariabler og SARS-CoV-2-smitte blant NorArtritt-pasienter $(n=27662)$. Tallene under kolonnegruppen «Pasienter» viser prosentvis fordeling for demografiske og medisinske variabler i hele populasjonen. Tallene under kolonnegruppen "covid-19" viser hvor mange som var SARS-CoV-2-positive blant alle i den gitte kategorien (for eksempel antall/andel positive blant pasienter i aldersgruppen 16 til 39 år). For eksempel ser vi høyere smitteforekomst i de yngste aldersgruppene. Se tabell 1 for forklaring av medikamenter.

\begin{tabular}{|c|c|c|c|c|}
\hline & \multicolumn{2}{|l|}{ Pasienter } & \multicolumn{2}{|c|}{ Covid-19 } \\
\hline & Antall & Andel (\%) & Antall & Andel (\%) \\
\hline \multicolumn{5}{|l|}{ Alder, år (n = 27 662) } \\
\hline $16-39$ & 3257 & 12 & 29 & 0,89 \\
\hline $40-59$ & 10469 & 38 & 87 & 0,83 \\
\hline $60-79$ & 12302 & 44 & 59 & 0,48 \\
\hline $80+$ & 1634 & 6 & 9 & 0,55 \\
\hline \multicolumn{5}{|l|}{ Kjønn (n = 27 662) } \\
\hline Kvinner & 16339 & 59 & 113 & 0,69 \\
\hline Menn & 11323 & 41 & 71 & 0,63 \\
\hline \multicolumn{5}{|c|}{ Diagnosegruppe (n = 27 662) } \\
\hline Revmatoid artritt & 12956 & 47 & 84 & 0,65 \\
\hline Psoriasisartritt & 7040 & 25 & 51 & 0,72 \\
\hline Spondyloartritt & 5385 & 19 & 34 & 0,63 \\
\hline Andre perifere artritter & 2281 & 8 & 15 & 0,66 \\
\hline \multicolumn{5}{|c|}{ Medikament: csDMARD ( $n=27662)$} \\
\hline Nei & 10992 & 40 & 77 & 0,70 \\
\hline Ja & 16670 & 60 & 107 & 0,64 \\
\hline \multicolumn{5}{|c|}{$\begin{array}{l}\text { Medikament: biologisk eller tsDMARD ( } \\
=27662 \text { ) }\end{array}$} \\
\hline Nei & 16204 & 59 & 110 & 0,68 \\
\hline Ja & 11458 & 41 & 74 & 0,65 \\
\hline \multicolumn{5}{|c|}{ Medikament: Prednisolon ( $\mathrm{n}=27$ 662) } \\
\hline Nei & 23361 & 84 & 156 & 0,67 \\
\hline $\mathrm{Ja}$ & 4301 & 16 & 28 & 0,65 \\
\hline \multicolumn{5}{|c|}{$\begin{array}{l}\text { Lav sykdomsaktivitet / remisjon ( } \mathrm{n} \\
=24858 \text { ) }\end{array}$} \\
\hline Nei & 6109 & 25 & 31 & 0,51 \\
\hline $\mathrm{Ja}$ & 18749 & 75 & 139 & 0,74 \\
\hline \multicolumn{5}{|c|}{ Siste registrerte KMI ( $n=26778)$} \\
\hline$<25$ & 10126 & 38 & 79 & 0,78 \\
\hline
\end{tabular}




\begin{tabular}{|lcccc|}
\hline & Pasienter & \multicolumn{3}{l|}{ Covid-19 } \\
\hline & Antall & Andel (\%) & Antall & Andel (\%) \\
\hline$\geq 25$ og $<30$ & 10394 & 39 & 64 & 0,62 \\
\hline$\geq 30$ og $<35$ & 4578 & 17 & 21 & 0,46 \\
\hline$\geq 35$ & 1680 & 6 & 15 & 0,89 \\
\hline Alle $(\mathbf{n}=\mathbf{2 7}$ 662) & 27662 & 100 & 184 & 0,67 \\
\hline
\end{tabular}

\section{Tabell 4}

Risikofaktorer for SARS-CoV-2-smitte blant NorArtritt-pasienter. Multippel logistisk regresjonsmodell $(\mathrm{n}=24418)$. Alle forklaringsvariabler er justert for de andre forklaringsvariablene. Ung alder og lav sykdomsaktivitet hang sammen med høyere forekomst av smitte. OR: oddsforhold (odds ratio); KI: konfidensintervall; CRP: C-reaktivt protein; KMI: kroppsmasseindeks.

\begin{tabular}{|c|c|c|c|}
\hline OR & $95 \%-\mathrm{KI}$ & & \\
\hline Alder (ikke-lineær kurve) & - & - & $<0,001$ \\
\hline Menn (ref.: kvinner) & 1,0 & 0,7 til 1,4 & 0,91 \\
\hline $\begin{array}{l}\text { Diagnose (ref.: revmatoid } \\
\text { artritt) }\end{array}$ & & & 0,96 \\
\hline Psoriasisartritt & 1,0 & 0,7 til 1,5 & 0,95 \\
\hline Spondyloartritt & 0,9 & 0,6 til 1,5 & 0,77 \\
\hline Andre perifere artritter & 0,9 & 0,5 til 1,5 & 0,62 \\
\hline Medikament: csDMARD ${ }^{1}$ & 0,9 & 0,7 til 1,3 & 0,64 \\
\hline $\begin{array}{l}\text { Medikament: biologisk eller } \\
\text { tsDMARD }^{1}\end{array}$ & 0,9 & 0,7 til 1,2 & 0,53 \\
\hline Medikament: Prednisolon ${ }^{1}$ & 1,2 & 0,7 til 1,8 & 0,52 \\
\hline $\begin{array}{l}\text { Lav sykdomsaktivitet / } \\
\text { remisjon }\end{array}$ & 1,6 & 1,1 til 2,6 & 0,02 \\
\hline Siste registrerte $\mathrm{CRP}^{2}, \mathrm{mg} / \mathrm{L}$ & 1,0 & 1,0 til 1,0 & 0,31 \\
\hline Siste registrerte $\mathrm{KMI}^{2}, \mathrm{~kg} / \mathrm{m}^{2}$ & 1,0 & 1,0 til 1,0 & 0,53 \\
\hline Antall komorbide tilstander ${ }^{2}$ & 1,1 & 1,0 til 1,2 & 0,09 \\
\hline
\end{tabular}

${ }^{1}$ Det er mulig for en pasient å bruke medikamenter i mer enn én medikamentgruppe. Se tabell 1 for forklaring av medikamentklasser.

${ }^{2}$ CRP-verdier $>100$ er satt til 10o. KMI-verdier $>50$ er satt til 50 . Antall komorbide tilstander $>_{5}$ er satt til 5 .

Av de 185 smittede ble 21 (11\%) innlagt i sykehus, hvorav 18 (10\%) hadde covid-19 som hoveddiagnose. Åtte (4\%) var innlagt i intensivavdeling, og syv (4\%) trengte mekanisk ventilasjon.

\section{Diskusjon}


I vår studie fant vi at pasienter med inflammatorisk leddsykdom hadde lavere kjønns- og aldersjustert forekomst av covid-19 enn den generelle befolkningen i 2020. I en metaanalyse av pasienter med revmatisk sykdom ble prevalensen av covid-19 funnet å være signifikant høyere enn i kontrollgruppen (24). . Denne pasientgruppen inkluderte også pasienter med vaskulitt og systemisk bindevevssykdom, som vanligvis har mer systemisk inflammasjon og mer alvorlig sykdom enn pasienter med inflammatorisk leddsykdom. Disse pasientene bruker også prednisolon i større grad. Den økte risikoen ble hovedsakelig funnet å kunne tilskrives prednisolonbruk. I vårt materiale fant vi ikke at pasienter som brukte prednisolon hadde $ø \mathrm{kt}$ forekomst av smitte.

Forekomsten av covid-19 var lavere i vår pasientgruppe enn i den generelle befolkningen. Vi tror dette skyldes at pasienter med kronisk sykdom i større grad enn friske har skjermet seg for situasjoner der de kunne bli utsatt for smitte. Resultatene fra regresjonsanalysen peker i samme retning - mindre smitte for pasienter med moderat eller høy sykdomsaktivitet. Ettersom hverken diagnose eller medikamentell behandling hadde innvirkning, skyldes trolig også dette at de sykeste pasientene i større grad har holdt seg borte fra potensielle smittesituasjoner. Tilsvarende er høyere forekomst blant yngre pasienter sannsynligvis uttrykk for at de hadde flere nærkontakter og tok større risiko enn de eldre.

En nederlandsk studie fant at pasienter med inflammatorisk leddsykdom hadde nesten dobbelt så høy etterlevelse av råd om isolasjon og sosial distansering som friske kontroller (25), og de som brukte biologiske sykdomsmodifiserende medikamenter isolerte seg $\mathrm{i}$ større grad enn resten. Om de sykeste pasientene med tyngst anti-revmatisk medikasjon i større grad beskytter seg mot smitte, kan det være en konfunderende faktor i vurderingen av i hvilken grad kronisk inflammatorisk leddsykdom og behandlingen av denne påvirker smitterisikoen.

Av de 185 smittede ble 18 (10 \%) innlagt i sykehus med covid-19 som hoveddiagnose. Antallet var for lavt til at det kunne gjøres statistiske analyser på dette materialet. Andelen med covid-19 i den generelle befolkningen som ble innlagt i sykehus var per 3. januar 2021 4,2\% (26). Andelen som trengte intensivopphold i den generelle befolkningen var o,8\%, mot $4 \% \mathrm{i}$ vårt materiale (206). Dette er ikke direkte sammenlignbart, da NorArtritt-pasientene har en annen alders- og kjønnssammensetning. Andelen innlagte i vårt materiale var lavere enn hva som er sett i studier av pasienter med revmatisk sykdom fra andre land. En studie fra USA viste at risikoen for innleggelse hos pasienter med revmatisk sykdom og covid-19 var blitt lavere i løpet av pandemien (27.). Dette forklares med at $\emptyset \mathrm{kt}$ testkapasitet bidro til å diagnostisere flere pasienter med mindre alvorlig sykdom i slutten av perioden. At vi i Norge har hatt vedvarende høy testkapasitet og diagnostisert mange med mild sykdom, kan forklare at andelen som ble innlagt i vårt materiale lå betydelig under det fra USA.

\section{STYRKER OG BEGRENSNINGER}

En styrke ved studien er Norges høye grad av testing for covid-19, også tidlig i pandemien $(\underline{28})$. Dette gjør at materialet også inneholder milde sykdomstilfeller som ikke trengte sykehusinnleggelse, og det gir dermed et riktigere bilde av risikoen for smitte. At laboratoriet melder positive prøver til MSIS, sikrer høy grad av rapportering og god oversikt over sykdomstilfeller. Studien omhandler en relativt stor kohort av pasienter med revmatisk leddsykdom.

NorArtritt har en total dekningsgrad på 6o \%, men dekningsgraden varierer mellom sykehusene. Sykehus med lav dekningsgrad har ofte valgt ut sine sykeste pasienter med tyngst antirevmatisk medikasjon for inklusjon, og i den grad utvalget til denne studien mistenkes å være skjevt, er det mot pasienter med mer alvorlig leddsykdom (17.). Siden vi ikke fant en overhyppighet av covid-19 i pasientgruppen, mener vi det er lite sannsynlig at inflammatorisk leddsykdom er en risikofaktor for covid-19.

De påviste forskjellene er pålitelige, og taler imot overhyppighet i pasientgruppen som helhet. Det var få smittede pasienter, noe som gjør at mangel på påviste forskjeller ikke innebærer at forskjeller ikke kan foreligge. Dette gjelder for eksempel eventuelle 
kjønnsforskjeller i underhyppigheten og forskjeller mellom de ulike revmatiske tilstandene eller knyttet til medikamentbruk. Siden bruken av prednisolon ofte er intermitterende og i varierende doser, er ikke nødvendigvis all prednisolonbruk registrert i NorArtritt. Opplysninger om prednisolon blir heller ikke oppdatert før ved neste kontroll, selv om kuren kan være avsluttet tidligere. Om pasientene brukte prednisolon i større eller mindre grad enn det som var registrert, er det mulig at prednisolon likevel hadde betydning for forekomsten, selv om vi ikke kunne vise dette.

\section{Konklusjon}

Pasienter med kronisk inflammatorisk leddsykdom hadde lavere kjønns- og aldersjustert forekomst av covid-19 enn den generelle befolkningen. Innad i pasientgruppen var yngre alder og lav sykdomsaktivitet knyttet til høyere smitteforekomst. Den mest sannsynlige forklaringen er at pasienter som på grunn av kronisk sykdom, høy alder eller høy sykdomsaktivitet er bekymret for å være i en risikogruppe, i større grad enn andre har beskyttet seg mot smitte.

Takk til MSIS for godt samarbeid rundt utlevering av data. Artikkelen er fagfellevurdert.

\section{LITTERATUR}

1. Doran MF, Crowson CS, Pond GR et al. Frequency of infection in patients with rheumatoid arthritis compared with controls: a population-based study. Arthritis Rheum 2002; 46: 2287-93. [PubMed] [CrossRef]

2. Franklin J, Lunt M, Bunn D et al. Risk and predictors of infection leading to hospitalisation in a large primary-care-derived cohort of patients with inflammatory polyarthritis. Ann Rheum Dis 2007; 66:308-12. [PubMed][CrossRef]

3. Ramiro S, Sepriano A, Chatzidionysiou Ket al. Safety of synthetic and biological DMARDs: a systematic literature review informing the 2016 update of the EULAR recommendations for management of rheumatoid arthritis. Ann Rheum Dis 2017; 76: 1101-36. [PubMed][CrossRef]

4. Mikuls TR, Johnson SR, Fraenkel L et al. American College of Rheumatology Guidance for the Management of Rheumatic Disease in Adult Patients During the COVID-19 Pandemic: Version 1. Arthritis Rheumatol 2020; 72:1241-51. [PubMed][CrossRef]

5. Norsk revmatologisk forening. Covid-19: Veileder for helsepersonell (revmatolog)- oppdatert veileder. https://www.legeforeningen.no/foreningsledd/fagmed/Norsk-revmatologiskforening/aktuelle-saker/2020/covid-19-oppdatert-veileder/ Lest 17.8.2021.

6. Zhong J, Shen G, Yang H et al. COVID-19 in patients with rheumatic disease in Hubei province, China: a multicentre retrospective observational study. Lancet Rheumatol 2020; 2: e557-64. [PubMed] [CrossRef]

7. Ferri C, Giuggioli D, Raimondo V et al. COVID-19 and rheumatic autoimmune systemic diseases: report of a large Italian patients series. Clin Rheumatol 2020;39:3195-204. [PubMed][CrossRef]

8. Pablos JL, Abasolo L, Alvaro-Gracia JM et al. Prevalence of hospital PCR-confirmed COVID-19 cases in patients with chronic inflammatory and autoimmune rheumatic diseases. Ann Rheum Dis 2020; 79: 1170-3. [PubMed][CrossRef]

9. Salvarani C, Bajocchi G, Mancuso P et al. Susceptibility and severity of COVID-19 in patients treated with bDMARDS and tsDMARDs: a population-based study. Ann Rheum Dis 2020; 79: 986-8. [PubMed] [CrossRef]

10. Michelena X, Borrell H, López-Corbeto M et al. Incidence of COVID-19 in a cohort of adult and paediatric patients with rheumatic diseases treated with targeted biologic and synthetic diseasemodifying anti-rheumatic drugs. Semin Arthritis Rheum 2020; 50: 564-70. [PubMed][CrossRef]

11. D'Silva KM, Serling-Boyd N, Wallwork R et al. Clinical characteristics and outcomes of patients with coronavirus disease 2019 (COVID-19) and rheumatic disease: a comparative cohort study from a 
12. Ye C, Cai S, Shen G et al. Clinical features of rheumatic patients infected with COVID-19 in Wuhan, China. Ann Rheum Dis 2020; 79: 1007-13. [PubMed][CrossRef]

13. Gianfrancesco M, Hyrich KL, Al-Adely S et al. Characteristics associated with hospitalisation for COVID-19 in people with rheumatic disease: data from the COVID-19 Global Rheumatology Alliance physician-reported registry. Ann Rheum Dis 2020; 79: 859-66. [PubMed][CrossRef]

14. Sarzi-Puttini P, Marotto D, Caporali R et al. Prevalence of COVID infections in a population of rheumatic patients from Lombardy and Marche treated with biological drugs or small molecules: A multicentre retrospective study. J Autoimmun 2021; 116. doi: 10.1016/j.jaut.2020.102545. [PubMed] [CrossRef]

15. Favalli EG, Monti S, Ingegnoli F et al. Incidence of COVID-19 in Patients With Rheumatic Diseases Treated With Targeted Immunosuppressive Drugs: What Can We Learn From Observational Data? Arthritis Rheumatol 2020; 72:1600-6. [PubMed][CrossRef]

16. Nystad W, Hjellvik V, Larsen IK et al. Underliggende tilstander hos voksne med covid-19. Tidsskr Nor Legeforen 2020; 140. doi: 10.4045/tidsskr.20.0512. [PubMed][CrossRef]

17. Norsk kvalitetsregister for artrittsykdommer. Årsrapport for 2019 med plan for forbedringstiltak. https://www.kvalitetsregistre.no/sites/default/files/2021-02/\%C3\%85rsrapport\%202019\%20Norartritt.pdf Lest 17.8.2021.

18. Whittaker R, Grøsland M, Buanes EA et al. Sykehusinnleggelser med covid-19 - en sammenligning av ulike datakilder. Tidsskr Nor Legeforen 2020;140. doi:10.4045/tidsskr.20.0759. [PubMed][CrossRef]

19. Direktoratet for e-helse. Kodeverket ICD-10 (og ICD-11).

https://www.ehelse.no/kodeverk/kodeverket-icd-10-og-icd-11 Lest 17.8.2021.

20. Anderson J, Caplan L, Yazdany J et al. Rheumatoid arthritis disease activity measures: American College of Rheumatology recommendations for use in clinical practice. Arthritis Care Res (Hoboken) 2012; 64: 640-7. [PubMed][CrossRef]

21. Machado P, Landewé R, Lie E et al. Ankylosing Spondylitis Disease Activity Score (ASDAS): defining cut-off values for disease activity states and improvement scores. Ann Rheum Dis 2011; 70: 47-53. [PubMed][CrossRef]

22. Statistisk sentralbyrå. Alders- og kjønnsfordeling i kommuner, fylker og hele landets befolkning (K) 1986-2021. https://www.ssb.no/statbank/table/o7459 Lest 17.8.2021.

23. R Core Team. R: A language and environment for statistical computing. R foundation for Statistical computing, Vienna Austria 2021. https://www.R-project.org/ Lest 17.8.2021.

24. Akiyama S, Hamdeh S, Micic D et al. Prevalence and clinical outcomes of COVID-19 in patients with autoimmune diseases: a systematic review and meta-analysis. Ann Rheum Dis 2020; 79. doi: 10.1136/annrheumdis-2020-218946. [PubMed][CrossRef]

25. Hooijberg F, Boekel L, Vogelzang EH et al. Patients with rheumatic diseases adhere to COVID-19 isolation measures more strictly than the general population. Lancet Rheumatol 2020; 2 : e583-5. [PubMed][CrossRef]

26. Folkehelseinstituttet. COVID-19 ukerapport uke 53. Publisert 6.1.2021. https://www.fhi.no/contentassets/8a971e7boa3c4ao6bdbf381ab52e6157/vedlegg/andre-halvar-2020/2021.01.06-ukerapport-uke-53-covid-19.pdf Lest 17.8.2021.

27. Jorge A, D'Silva KM, Cohen A et al. Temporal trends in severe COVID-19 outcomes in patients with rheumatic disease: a cohort study. Lancet Rheumatol 2021;3: e131-7. [PubMed][CrossRef]

28. Worldometer 2021. Coronavirus Cases. https://www.worldometers.info/coronavirus/\#countries. Lest 16.4.2021.

29. Folkehelseinstituttet. Statistikk om koronavirus og covid-19. Publisert 9.3.2020. https://www.fhi.no/sv/smittsomme-sykdommer/corona/dags--og-ukerapporter/dags--ogukerapporter-om-koronavirus/ Lest 17.8.2021.

Publisert: 11. oktober 2021. Tidsskr Nor Legeforen. DOI: 10.4045/tidsskr.21.0362

Mottatt 30.4.2021, første revisjon innsendt 15.6.2021, godkjent 17.8.2021.

Publisert under åpen tilgang CC BY-ND. Lastet ned fra tidsskriftet.no 26. april 2023. 